LATIN AMERICA'S COLD WAR 



\section{LATIN AMERICA'S COLD WAR}

\section{HAL BRANDS}

HARVARD UNIVERSITY PRESS

Cambridge, Massachusetts, and London, England 
Copyright (C 2010 by Hal Brands

All rights reserved

Printed in the United States of America

Library of Congress Cataloging-in-Publication Data

Brands, Hal, 1983-

Latin America's Cold War / Hal Brands.

p. $\mathrm{cm}$.

Includes bibliographical references and index.

ISBN 978-0-674-05528-5

1. Latin America-History-1948-1980. 2. Latin America-

History-1980- 3. Latin America-Politics and government-1948-1980.

4. Latin America-Politics and government-1980- 5. Latin America-Foreign relations-1948-1980. 6. Latin America-Foreign relations-1980- 7. Cold War-Influence. 8. World politics-1945-1989. I. Title.

F1414.2B693 2010

980.03-dc22 2010006742 